\title{
Using Gambusia affinis growth and condition to assess estuarine habitat quality: a comparison of indices
}

\author{
Bryan P. Piazza ${ }^{1,3, *}$, Megan K. La Peyre ${ }^{2}$ \\ ${ }^{1}$ School of Renewable Natural Resources, Louisiana State University Agricultural Center, Baton Rouge, \\ Louisiana 70803, USA \\ ${ }^{2}$ US Geological Survey, Louisiana Fish and Wildlife Cooperative Research Unit, School of Renewable Natural Resources, \\ Louisiana State University Agricultural Center, Baton Rouge, Louisiana 70803, USA \\ ${ }^{3}$ Present address: The Nature Conservancy, PO Box 4125, Baton Rouge, Louisiana 70821, USA
}

\begin{abstract}
Numerous indices have been used to estimate fish growth and condition; however, differences in sensitivity and reliability of the methods have hampered efforts to identify appropriate indicators for routine evaluation of habitat quality in the field. We compared common morphometric (length, weight, somatic growth, length-weight condition) and biochemical (RNA:DNA ratio, relative DNA content, energy density) growth indices on the same wild-caught mosquitofish Gambusia affinis to examine their usefulness as indicators of habitat quality. A laboratory experiment was used to quantify growth rates of wild-caught $G$. affinis under different feeding treatments. Field studies consisted of both a short-term enclosure experiment $(10 \mathrm{~d})$ and weekly $(7 \mathrm{wk})$ fish collections to compare growth indices in managed inflow and reference marshes during a winter/spring freshwater pulse event in upper Breton Sound, Louisiana, USA. Marshes flooded by restored freshwater pulses were capable of producing optimum growth $\left(0.001 \mathrm{~g} \mathrm{DW} \mathrm{d}^{-1}\right.$; DW = dry weight) and energetically valuable habitat (>6000 $\mathrm{cal} \mathrm{g}^{-1} \mathrm{DW}$ ) for trophic transport. Because of differences in timing of response, morphometric and biochemical indices were generally not directly correlated, but there was clear agreement in direction and magnitude of response. The most striking difference in timing was that biochemical indices (RNA:DNA) responded more slowly to treatments than did morphometric growth indices. While gross patterns are comparable between indicators, differences in sensitivity and response time between indicators suggest that choice of indicator needs to be accounted for in interpretation and analysis of effects.
\end{abstract}

KEY WORDS: Growth $\cdot$ Energy density $\cdot$ RNA:DNA ratio $\cdot$ Resident species $\cdot$ Poeciliidae $\cdot$ Estuary Fish · Louisiana

Resale or republication not permitted without written consent of the publisher

\section{INTRODUCTION}

Rapid growth rates have been shown to confer ecological advantage in fishes and reflect favorable conditions such as abundant food, optimal temperatures, and appropriate physical habitat (Amara et al. 2007). Indicators of growth and condition provide integrative measures of the effects of both biotic and abiotic environmental influences on fish (Searcy et al. 2007, Zapfe \& Rakocinski 2008). As such, these indicators have been used to compare habitat quality (Amara et al.
2007, Haas et al. 2009, Vasconcelos et al. 2009), examine fish response to pollution (Amara et al. 2007) and climatic variability (Teal et al. 2008), inform management of fisheries stocks or endangered species (Lorenzen \& Enberg 2002), compare nursery grounds (Gilliers et al. 2004, Vasconcelos et al. 2009), and assess restored habitats (La Peyre et al. 2007). Over the years, researchers have identified and used several morphometric and biochemical correlates of growth; however, differences in sensitivity and reliability of the methods and the need for species-specific standardization for 
some methods have hampered efforts to identify appropriate indicators for routine evaluation of habitat quality in the field.

Increasing threats to fish populations arising from both natural events and anthropogenic activities have led to extensive estuarine restoration activities around the world and a critical need for appropriate indicators to assess the relationship between restored and altered habitat and their associated fish populations (Madon 2008). In particular, restoration in large-river delta environments (e.g. Williamson River Delta, Sacramento-San Joaquin River Delta, Mississippi River Delta) often focuses on the reconnection of the riverine flood events that provide extended access to highquality, ephemerally flooded estuarine habitats for transient and resident fishes (Kneib 2000). These flooded habitats have been shown to be functionally valuable for fish growth due to an abundance of high quality food sources (Madon 2008). In coastal Louisiana, the Caernarvon Freshwater Diversion (Caernarvon) is one such project that restores the annual spring flood pulse to Breton Sound, Louisiana, with the goal of benefiting fish populations. However, managers lack the tools to fully evaluate the impacts of Caernarvon on fish populations or to assess the quality of the downstream habitat in relation to habitat not receiving the restored annual flood pulse.

Numerous measures of growth and condition have been used in both carefully controlled laboratory studies and in a range of field studies (Bergeron 1997, MercadoAllen et al. 2006, Amara et al. 2007, Vasconcelos et al. 2009). However, in studies that examine multiple indices on the same fish, low correlations are frequently found between different indices, indicating that the choice of growth and condition indicators of fish may affect conclusions (Gilliers et al. 2004, Vasconcelos et al. 2009). The lack of correlation among indices has been ascribed to differences in temporal response of the indices, suggesting that the timescale of the study could be a critical factor influencing the interpretation of results (Gilliers et al. 2004). This difference in temporal response likely results from differences in sensitivity among indices. For example, biochemical indices are often cited as being ideal indicators owing to their higher sensitivity and quick detection of growth differences at the cellular level (Rooker et al. 1997, Buckley et al. 1999). However, this high sensitivity may actually decrease the ability of biochemical indices to differentiate habitat quality in field studies, because results can be extremely variable because of numerous factors (i.e. ontogeny, temperature, species), which may ultimately mask differences in habitat quality (Gilliers et al. 2004, Vasconcelos et al. 2009). Therefore, several independent methods may be necessary to minimize problems caused by biases in any one of the methods (Gilliers et al. 2004).
The goals of this study were to (1) evaluate the effects of the restored annual flood pulse and the provision of ephemerally flooded habitat on growth and condition of a ubiquitous marsh resident, the mosquitofish Gambusia affinis, and (2) assess and compare several common morphometric (mean weight, mean length, somatic growth, length-weight condition) and biochemical (RNA:DNA, relative DNA content [DNA: DW; DW = dry weight], energy density) growth indices. G. affinis is an ideal species for this study as it rapidly assembles in and uses flooded marsh habitat when available (Kneib 2000, Piazza \& La Peyre 2007). To meet these goals, we used a controlled laboratory study, as well as 2 field experiments that were conducted during a pulsed freshwater release into upper Breton Sound, Louisiana.

\section{MATERIALS AND METHODS}

Study area. Breton Sound is a 271000 ha estuary in the Mississippi River deltaic plain in southeast Louisiana (Fig. 1). It is microtidal and consists of bays, lakes, bayous, canals, and a relict Mississippi River distributary (Bayou Terre aux Boeufs) that separates the basin geographically and hydrologically. Marshes within the basin consist of fresh, intermediate, brackish, and saline vegetation. This study took place in emergent marshes within the upper Breton Sound basin, which are subject to flooding from Caernarvon. Caernarvon became operational in 1991 and was designed to moderate salinities and reintroduce controlled river inflows to Breton Sound. Yearly winter/ spring experimental high-flow releases began in spring 2001 to simulate seasonal flood-pulse events and mimic springtime flooding conditions that characterize river-dominated Gulf Coast estuaries (Rozas 1995). Pulses release periodic large fluxes of Mississippi river water into the basin and are capable of inundating upper basin marshes (inflow marshes; $\sim 5700 \mathrm{ha}$ ) for extended periods (Snedden et al. 2007).

In 2007, one sustained high-discharge event was conducted (January through March). As in other Gulf Coast estuaries, without the riverine pulse, inundation of upper basin marshes is dominated by meteorological forcing (Rozas 1995). These conditions are found in the marshes east of Bayou Terre aux Boeufs, which are hydrologically separated from diversion flow, creating a reference area (reference marshes, Rozas et al. 2005). Dominant emergent vegetation in both inflow and reference marshes consists of Spartina patens (Saltmeadow cordgrass) and Schoenoplectus americanus (Chairmaker's bulrush).

Laboratory growth experiment. The goals of this experiment were to (1) standardize techniques of measuring growth and condition for wild-caught Gam- 


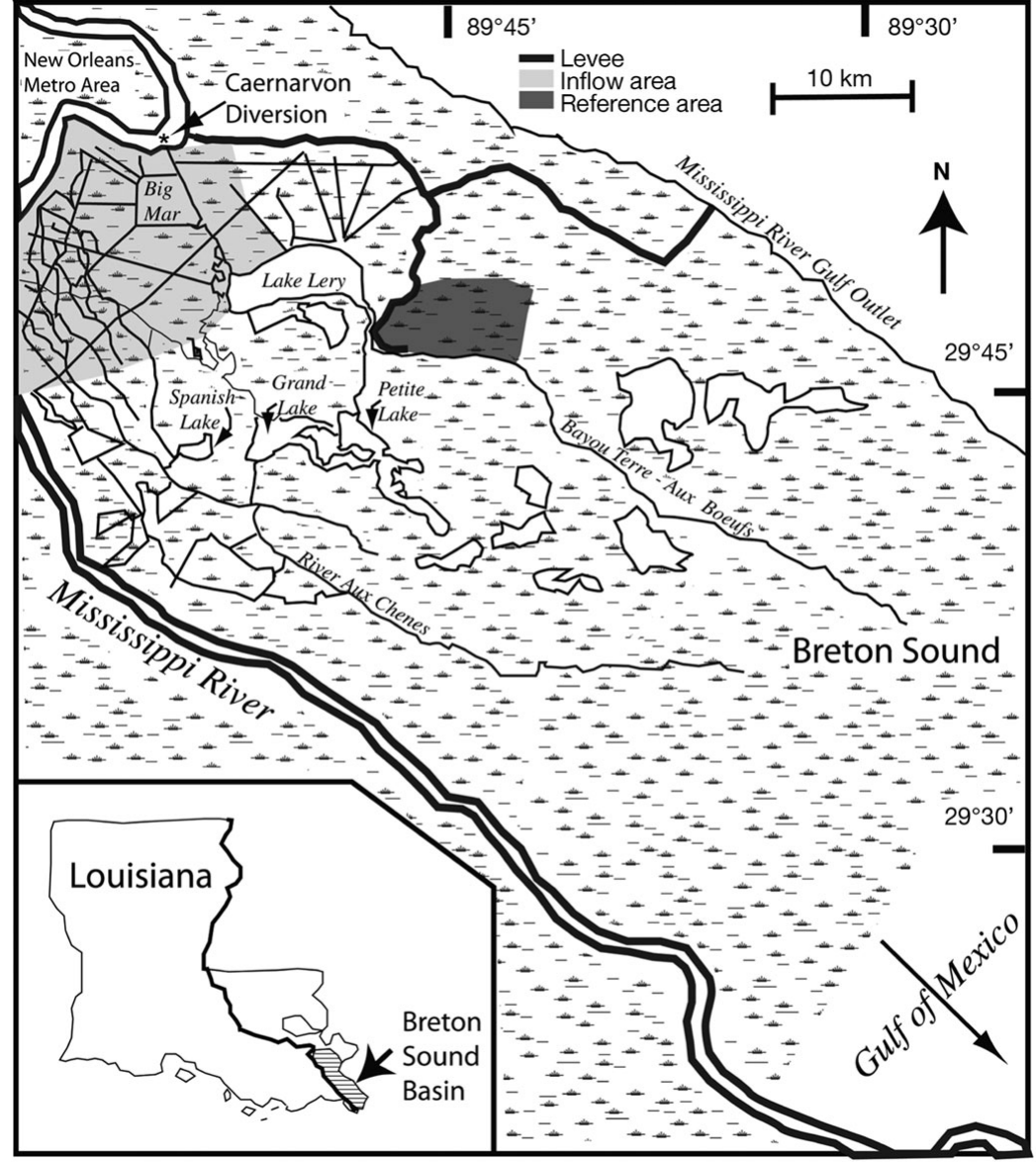

Fig. 1. Breton Sound estuary, Louisiana, and the location of the Caernarvon Freshwater Diversion. Shaded areas show the location of the inflow (light gray) and reference (dark gray) areas used in this study. Map taken from Piazza \& La Peyre (2007)

busia affinis, and (2) compare common growth indices (somatic growth, length-weight condition, RNA:DNA ratio, relative DNA content) on the same wild-caught fish under controlled laboratory conditions. The experiment was necessary because few studies have investigated the growth of $G$. affinis and none has calculated RNA:DNA ratio or relative DNA content for this species, and nucleic acid concentrations vary widely across fish species (Pedersen 1971). Additionally, few studies use wild-caught fish for RNA/DNA experimentation, but rather use lab-reared cohorts under strict control.

Experimental setup and design: Experimental fish were harvested with dip nets in upper Breton Sound estuary (outside the inflow and reference areas) during July 2006. Upon capture, fish were placed in an aerated holding tank, transported back to Louisiana State University (LSU), and acclimated for 2 wk in 3 separate holding tanks (142 l). During the acclimation period, all fish were fed commercial fish food (Omega One flake fish food) once daily.
Twenty experimental aquaria (76 l) were set up 1 mo prior to experimental initiation and identically equipped with undergravel filtration and a common air source. Water temperature in the experimental aquaria was kept at ambient temperature $\left(18\right.$ to $\left.19^{\circ} \mathrm{C}\right)$, and the light:dark cycle was $12 \mathrm{~h}$ throughout the experiment.

Each aquarium was randomly assigned to 1 of 2 treatments (fed or starved), and these laboratory treatments served as a proxy for habitat quality. Starved fish were not fed throughout the $10 \mathrm{~d}$ experiment. Fed fish were provided commercial fish food (Omega One flake fish food) ad libitum every $6 \mathrm{~h}$ (08:00, 14:00, 20:00, 02:00 h) until they did not actively strike food for $1 \mathrm{~min}$ and left some food floating on the surface.

Thirty-three experimental fish were randomly chosen and stocked to each of the 20 aquaria (total $\mathrm{N}=660$ ). Mean weight (length) of stocked fish was $0.12 \pm 0.01 \mathrm{~g}$ WW $(22.8 \pm 0.65 \mathrm{~mm}$; $\mathrm{WW}=$ wet $\mathrm{wt}$ ) in the fed treatment and $0.13 \pm 0.02 \mathrm{~g} \mathrm{WW}(22.6 \pm 1.3 \mathrm{~mm})$ in the starved treatment. Experimental fish were acclimated (unfed) for $1 \mathrm{~d}$. At the end of the acclimation period and before the initial feeding, 3 fish were removed from each tank and processed for initial condition measurement (Day 0). Three fish were then removed from each tank daily $(07: 00 \mathrm{~h})$ for somatic growth and tissue analysis ( 3 fish $\times 20$ tanks $=$ 60 fish $^{-1}$ ) for a total of $11 \mathrm{~d}$ (220 tank means). Upon removal, fish were weighed $(\mathrm{g})$, measured $(\mathrm{mm})$, and a piece of white muscle tissue ( 30 mg) was dissected from the side of each fish for nucleic acid extraction and calculation of nucleic acid indices.

Data analysis: Wet weights of experimental fish were converted to dry weights by using a speciesspecific regression equation for Gambusia affinis (B. P. Piazza \& M. K. La Peyre unpubl. data):

$$
\mathrm{DW}=-0.002934+0.206633(\mathrm{WW})
$$

Daily somatic growth (g DW, mm) for each treatment was determined by regression analysis (model growth = day) on a daily tank mean of harvested fish $\left(\mathrm{n}=3 \mathrm{fish}_{\mathrm{tank}}^{-1} \mathrm{~d}^{-1}\right)$, and differences in the slopes of regression lines were tested following the procedure of Zarnoch (2009), with the assumption that the intercepts may not be equal. Linear regression was also 
used to investigate daily trends in RNA:DNA ratio and relative DNA content. All results were considered significant at $\alpha=0.05$.

In order to determine the effect of ontogeny on growth dynamics, we further classified experimental fish as juveniles or adults and repeated the statistical analyses for each ontogenetic stage. We used only females for classification because (1) there were few males in the experimental populations and (2) females devote significantly more anabolic energy to gonad development and embryo growth as they age (Vondracek et al. 1988). Using the methods of Hughes (1985) and Vondracek et al. (1988), we classified females <23 mm total length (TL) as juveniles and females $\geq 23 \mathrm{~mm}$ TL as adults.

Correlation analysis was used to investigate the relationship between morphometric growth indices, individual nucleic acid concentrations, RNA:DNA ratio, and relative DNA content. The coefficient of variation $(\mathrm{CV})$ was calculated as an overall measure of variability of the individual nucleic acid measurements, RNA:DNA ratio, and relative DNA content (Weber et al. 2003).

Field Expt 1, on enclosure growth. This $10 \mathrm{~d}$ field experiment involved the measurement of growth on wild-caught Gambusia affinis that were placed in enclosures in the field. The goal was to examine the response of multiple growth indices (somatic growth, length-weight condition, RNA:DNA ratio, and relative DNA content) as indicators of short-term response to restored freshwater inflow.

Experimental setup and design: In spring 2007, during the freshwater release, wild Gambusia affinis were caught with dip nets in upper Breton Sound estuary (outside both inflow and reference areas) and acclimated for $24 \mathrm{~h}$. Eight enclosures (208 l; $0.27 \mathrm{~m}^{2}$ ) were randomly placed on the flooded marsh surface within each treatment area during a high-flow pulse event and stocked at a density (5 fish enclosure ${ }^{-1}$ ) that reflected the ambient density of $G$. affinis in flooded marshes during 2005 and 2006 winter/spring pulse releases (Piazza \& La Peyre 2007). Enclosures were deployed $6 \mathrm{wk}$ after the pulse event began, to account for any lagged system responses that may result during pulsed freshwater releases. At the time of deployment, water temperature $\left({ }^{\circ} \mathrm{C}\right)$, conductivity $(\mathrm{mS})$, salinity (psu), and dissolved oxygen $\left(\mathrm{mg} \mathrm{l}^{-1}\right)$ were measured with a handheld YSI 556 MPS (YSI Environmental). Turbidity (NTU; nephelometer turbidity units) was measured with a fluorometer (Aquaflour 8000, Turner Designs). Water depth at each enclosure site fluctuated naturally during the experiment.

Experimental fish were all adults. Mean weight (length) upon stocking was $0.30 \pm 0.02 \mathrm{~g} \mathrm{WW}(30.6 \pm$ $0.50 \mathrm{~mm}$ ) in the inflow area and $0.33 \pm 0.02 \mathrm{~g} \mathrm{WW}$
$(31.7 \pm 0.51 \mathrm{~mm})$ in the reference area. Each experimental fish was uniquely marked (fin clip) for identification and was measured (TL, standard length [SL], weight) upon deployment and retrieval, $10 \mathrm{~d}$ later. Additionally upon retrieval, a random sample of 3 fish from each enclosure was chosen for RNA/DNA analysis, and a piece of white muscle tissue ( 30 mg) was dissected from the side of each fish for nucleic acid extraction.

Data analysis: Wet weights of experimental fish were converted to dry weights, and daily somatic growth $(\mathrm{Gw})$ was calculated by using the equation

$$
\text { Gw }\left(\mathrm{g} \mathrm{DW} \mathrm{d}^{-1}\right)=\left(\ln \mathrm{DW}_{\mathrm{t} 2}-\ln \mathrm{DW}_{\mathrm{t} 1}\right) / 10 \mathrm{~d}
$$

Univariate ANOVA was used to investigate treatment differences in somatic growth, RNA:DNA ratio, and relative DNA content (response variable = treatment). Differences in environmental variables were compared by treatment using ANOVA. Growth rates and nucleic acid indices from individual fish recovered from each enclosure were averaged before statistical testing to ensure that growth observations were independent.

Field Expt 2, on through-pulse field collection. This experiment involved discrete collection of wild Gambusia affinis and measurement of growth indices for these individuals weekly through the pulse event. The goal was to examine the response of multiple growth indices (somatic growth, RNA:DNA ratio, relative DNA content, length-weight condition, energy density) as indicators of longer-term temporal response to freshwater input.

Experimental design: We collected wild Gambusia affinis with a dip net at several randomly chosen sites across flooded inflow and reference marshes through the experimental flood pulse event. Collections began on the first day of the pulse release and were made weekly for 7 wk (January 6 through March 12), resulting in a total of 2038 wild-caught $G$. affinis. Discharge during the extended pulse was approximately $169 \mathrm{~m}^{3}$ $\mathrm{s}^{-1}$. Environmental variables were measured (as above) each week at the time of fish collection.

Immediately upon capture, each fish was weighed (g) and measured (TL, mm) and randomly divided into 2 groups. One group ( $\mathrm{n}=15 \mathrm{fish}_{\mathrm{wk}} \mathrm{w}^{-1}$ from each treatment area) was randomly selected from the total fish pool for RNA/DNA analysis, and a piece of white muscle tissue ( $30 \mathrm{mg}$ ) was immediately dissected from the side of each fish for nucleic acid extraction. This group ( $\mathrm{N}=210$ fish) provided comparison of morphometric growth indices and nucleic acid indices (RNA:DNA ratio and relative DNA content). Results were not compared by ontogeny as in the laboratory experiment because of the paucity of juveniles in the sample $(\mathrm{N}=$ 10 inflow; $N=1$ reference). The second group (com- 
posed of the remaining fish; $\mathrm{N}=1828$ fish) was used for analyses of length-weight condition and energy density. These fish were immediately frozen in an ice slurry and transported back to the laboratory where they were measured (length $\mathrm{mm}$, WW g) for lengthweight condition analysis and processed for energy density analysis.

Data analysis: Wet weights of experimental fish were converted to dry weights, and weekly growth was determined for each treatment by regression analysis performed on a weekly sample mean of collected fish. Differences in the slopes of regression lines were tested following the procedure of Zarnoch (2009) with the assumption that the intercepts may not be equal. Linear regression was also used to investigate weekly trends in RNA:DNA ratio, relative DNA content, and energy density.

Correlation analysis was used to investigate the relationship between morphometric growth indices, individual nucleic acid concentrations, RNA:DNA ratio, and relative DNA. The CV was calculated as an overall measure of variability of the individual nucleic acid measurements, RNA:DNA ratio, and relative DNA content (Weber et al. 2003). Differences in environmental variables were compared by treatment, week, and treatment $\times$ week interactions using multivariate analysis of variance (MANOVA). Significant MANOVA models were investigated further with univariate ANOVA.

Experimental protocols. The following protocols were performed: nucleic acid indices, length-weight condition, and energy density.

Nucleic acid indices: Immediately upon harvest, a single piece of white muscle tissue ( 30 mg) was dissected from the side of each fish for nucleic acid extraction. Each sample was weighed, immediately transferred to sterilized, RNAse/DNAse-free microcentrifuge tubes filled with $400 \mu \mathrm{l}$ RNAlater (Qiagen), refrigerated overnight, and stored $\left(-80^{\circ} \mathrm{C}\right)$. Each tissue sample was removed from the freezer, thawed, pulverized in a mortar and pestle under liquid nitrogen, and homogenized in a QIAshredder spin column (Qiagen) under a buffer. RNA and DNA purification was performed simultaneously with the AllPrep DNA/RNA Mini Kit (Qiagen). This kit allowed the parallel purification of both cellular RNA and DNA from the same tissue sample. The precision of the assay was experimentally tested on subsamples from wild-caught Gambusia affinis. Test results showed no significant difference in RNA:DNA ratio between tissue subsamples taken from each fish $\left(F_{2,18}=1.47 ; \mathrm{p}=0.25 ; \mathrm{N}=60\right)$, and the precision of the technique as measured by the $\mathrm{CV}$ was $12 \%$ (Piazza 2009).

Once purified, concentrations of both RNA (ng $\left.\mu^{-1}\right)$ and DNA (ng $\mu^{-1}$ ) were measured with nucleic acidspecific dye assays in a 96-well plate format. RNA con- centrations were measured with the Quant-IT RiboGreen RNA Kit (Item R11490, Molecular Probes, Invitrogen). Concentrations of DNA were measured with the Quant-IT dsDNA Broad-Range Assay Kit (Item MP3310, Molecular Probes, Invitrogen). Duplicate repetitions of each assay (RNA and DNA) were performed for all samples.

Fluorescence measurements were made on a Cytofluor II multi-well fluorescence plate reader (PerSeptive Biosystems), set at 480/535 nm (excitation/ emission) for both RNA and DNA measurements. Fluorescence values (nm) for samples were converted to concentrations with the standard curves. DNA standard curves were constructed with 8 different concentrations of dsDNA $\left(0,5,10,20,40,60,80,100 \mathrm{ng} \mathrm{\mu l}^{-1}\right.$; Quant-IT dsDNA Broad-Range Assay Kit). RNA standard curves were constructed with 5 dilutions of $16 \mathrm{~s}$ and 23s rRNA from Escherichia coli $(0,1,5,25,50 \mathrm{ng}$ $\mathrm{ml}^{-1}$; Quant-IT RiboGreen RNA Kit). RNA and DNA concentrations were standardized to $1 \mathrm{mg}$ of tissue weight $\left(\mu \mathrm{g} \mathrm{mg}^{-1}\right)$, and RNA:DNA ratio was expressed as the ratio of concentrations.

The relative DNA content was expressed as the ratio of the DNA concentration from an individual experimental fish to the dry weight of that fish (DNA:DW). This ratio has been recommended for further study as a reliable nucleic acid-based indicator of short-term growth (Bergeron 1997, Buckley et al. 1999).

Length-weight condition: Fish condition was determined with the approach used by Vila-Gispert \& Moreno-Amich (2001) and Oliva-Paterna et al. (2003). A univariate analysis of covariance (ANCOVA) was conducted on weight (dependent variable) and length (covariate) variables, which were each logtransformed to ensure linearity. Homogeneity of slopes of dependent-covariate relationships was tested with an ANCOVA model design that included the pooled covariate-factor interaction. In cases where the slopes were homogeneous, a standard ANCOVA was used to test for differences between treatments at the $y$ intercept. In cases where the slopes were heterogeneous, the mean weights were tested for equality at the overall mean of the covariate.

Energy density: Experimental fish were dried to a constant weight $\left(50^{\circ} \mathrm{C}, 48 \mathrm{~h}\right)$, weighed (g DW), and pulverized using a combination of mortar and pestle and a handheld electric coffee grinder. Analysis of energy density ( $\mathrm{cal} \mathrm{g}^{-1}$ ) was done on $1 \mathrm{~g}$ (DW) nekton pellets (Parr model 2811 pellet press) with a Parr 6200 isoperibol oxygen bomb calorimeter (oxygen bomb model 1108). Each pellet represented numerous individuals collected in a specific sample, and the number was dependent on the size of the individuals caught. Enough experimental Gambusia affinis were captured to yield a total of $\mathrm{N}=36$ pellets (22 inflow, 14 refer- 
ence) for calorimetry analysis. This subset of experimental fish was used to compare energy density and length-weight condition.

\section{RESULTS}

\section{Laboratory growth experiment}

Fish recovery

A total of 610 fish were recovered, with 50 (8\%) deaths during the experiment. Fish death began after $5 \mathrm{~d}$ and occurred evenly in tanks containing starved $(50 \%)$ and fed $(50 \%)$ fish. Nucleic acids were successfully extracted from 545 experimental fish (515 female, 30 male), approximately evenly split between adults $(55 \%)$ and juveniles $(45 \%)$. Somatic and nucleic acid growth indices were calculated from 207 tank means.

Fish growth

Regression analysis showed significant daily somatic growth of fish from the fed treatment for both weight (Weight $[\mathrm{g} \mathrm{DW}]=0.001[\mathrm{~d}]+0.026 ; \mathrm{r}^{2}=0.05 ; \mathrm{p}=0.02$; $\mathrm{N}=104$ ) and total length (Length $[\mathrm{mm}]=0.19[\mathrm{~d}]+$ $\left.22.61 ; r^{2}=0.05 ; p=0.02 ; N=104\right)$. Starved fish showed zero daily growth in weight (Weight $[\mathrm{g} \mathrm{DW}]=-0.0004$ $[\mathrm{d}]+0.023 ; \mathrm{r}^{2}=0.02 ; \mathrm{p}=0.17 ; \mathrm{N}=104$ ) or length (Length $[\mathrm{mm}]=0.01[\mathrm{~d}]+22.48 ; \mathrm{r}^{2}=0.00 ; \mathrm{p}=0.90 ; \mathrm{N}=$ 104). Slopes were significantly different by treatment for daily change in weight $(F=36.06, \mathrm{p}<0.0001)$ and length $(F=10.62$, $\mathrm{p}=0.002)$.

Adult females had higher overall mean growth $\left(1.81 \pm 0.29 \% \mathrm{~d}^{-1}, \mathrm{~N}=64\right)$ in tanks containing fed fish, as compared to female juveniles $\left(0.12 \pm 0.06 \% \mathrm{~d}^{-1}, \mathrm{~N}=\right.$ 68). Conversely, adult females from the tanks containing starved fish showed the highest mean weight loss $\left(-0.64 \pm 0.23 \% \mathrm{~d}^{-1}, \mathrm{~N}=72\right)$ as compared to female juveniles $\left(0.005 \pm 0.07 \% \mathrm{~d}^{-1}, \mathrm{~N}=56\right)$.

\section{Nucleic acid indices}

RNA:DNA ratio and relative DNA content were highly variable throughout the experiment (Table 1). Nucleic acid concentrations were correlated with each other $(\mathrm{r}=0.44 ; \mathrm{p}<0.0001 ; \mathrm{N}=207)$ and RNA:DNA ratio (RNA-r $=0.72 ; \mathrm{p}<0.0001 ;$ DNA-r $=-0.16 ; \mathrm{p}<0.02$; $\mathrm{N}=207$ ). Regression analysis showed significant daily increases in RNA:DNA ratio for both fed fish $\left(\right.$ RNA:DNA $=0.82[\mathrm{~d}]+0.62 ; \mathrm{r}^{2}=0.30 ; \mathrm{p}<0.0001 ; \mathrm{N}=$ 104) and starved fish (RNA:DNA $=0.34[\mathrm{~d}]+3.93 ; \mathrm{r}^{2}=$ $0.09 ; \mathrm{p}=0.003 ; \mathrm{N}=103$ ), with a greater increase in fed
Table 1. Gambusia affinis. Laboratory Expt, on growth. Summary statistics by treatment for cellular RNA and DNA concentrations and nucleic acid growth indices. Nucleic acids were purified from wild-caught $G$. affinis caught in upper Breton Sound, Louisiana, during summer 2007 and used in the $10 \mathrm{~d}$ laboratory feeding experiment. Fed treatment: $\mathrm{N}=$ 104, starved treatment: $\mathrm{N}=103$. Means are based on $\mathrm{N}=207$ tank means. DW = dry weight

\begin{tabular}{|c|c|c|}
\hline Growth/condition index & Fed & Starved \\
\hline \multicolumn{3}{|l|}{ RNA $\left(\mu \mathrm{g} \mathrm{mg}^{-1}\right)$} \\
\hline Mean $\pm \mathrm{SE}$ & $1.95 \pm 0.17$ & $3.31 \pm 0.22$ \\
\hline Range & 0.23 to 11.59 & 0.10 to 13.15 \\
\hline CV $(\%)$ & 91 & 66 \\
\hline \multicolumn{3}{|l|}{ DNA $\left(\mu g \mathrm{mg}^{-1}\right)$} \\
\hline Mean \pm SE & $0.52 \pm 0.03$ & $0.63 \pm 0.03$ \\
\hline Range & 0.14 to 2.06 & 0.19 to 1.95 \\
\hline $\mathrm{CV}(\%)$ & 55 & 48 \\
\hline \multicolumn{3}{|l|}{ RNA:DNA ratio } \\
\hline Mean $\pm \mathrm{SE}$ & $4.51 \pm 0.44$ & $5.53 \pm 0.35$ \\
\hline Range & 0.56 to 31.47 & 0.34 to 19.31 \\
\hline $\mathrm{CV}(\%)$ & 101 & 64 \\
\hline \multicolumn{3}{|l|}{ DNA:DW } \\
\hline Mean \pm SE & $0.02 \pm 0.00$ & $0.04 \pm 0.00$ \\
\hline Range & 0.00 to 0.16 & 0.00 to 0.43 \\
\hline $\mathrm{CV}(\%)$ & 98 & 119 \\
\hline
\end{tabular}

fish as compared to starved fish. However, slopes were not different by treatment for RNA:DNA $(F=0.03, \mathrm{p}=$ $0.87)$. Relative DNA content showed significant daily decrease in fed fish (DNA:DW $=-0.0002[\mathrm{~d}]+0.03 ; \mathrm{r}^{2}=$ $0.11 ; \mathrm{p}=0.0004 ; \mathrm{N}=104$ ) and no significant daily relationship for starved fish (DNA:DW $=-0.002[\mathrm{~d}]+0.05$; $\left.r^{2}=0.01 ; p=0.25 ; N=104\right)$. Slopes were different by treatment for relative DNA content $(F=9.54, \mathrm{p}=$ 0.002). Separate analyses of juvenile and adult fish showed similar results for nucleic acid indices.

\section{Length-weight condition}

Fish condition across all days was tested at the overall mean weight $(0.82 \mathrm{~g} \mathrm{WW})$ because of the heterogeneity of slopes. Length-weight condition was significantly greater in fed fish $\left(y=3.0096 x+2.3841 ; r^{2}=0.88\right)$ than starved fish $\left(y=2.7522 x+2.4228 ; r^{2}=0.82 ;\right.$ Fig. 2). Analysis of length-weight condition by day showed no difference in the condition of fish by treatment at Day 0 (initial condition) and significantly greater condition for fed fish each day thereafter (Days 1 through 10).

\section{Comparison of techniques}

RNA and DNA concentrations, as well as relative DNA content, were significantly negatively correlated 

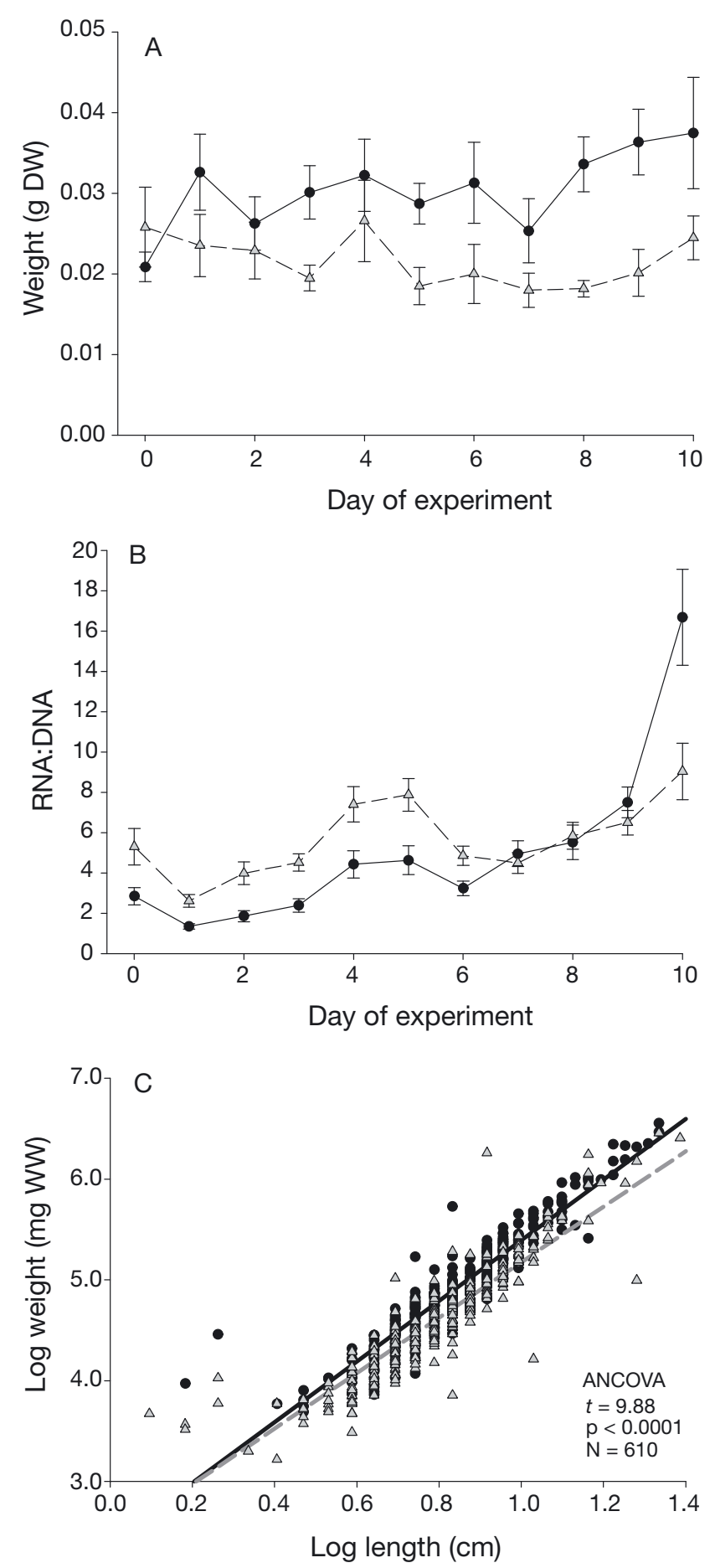

Fig. 2. Gambusia affinis. Lab Expt, on growth. Comparison of (A) daily mean weight, (B) RNA:DNA ratio, and (C) lengthweight condition for wild-caught $G$. affinis through a $10 \mathrm{~d}$ laboratory growth experiment. Fish in the fed treatment were fed a commercial flake food ad libitum every $6 \mathrm{~h}$ for $10 \mathrm{~d}$. Fish in the starved treatment were withheld food during the $10 \mathrm{~d}$ period. Comparisons of growth rate and RNA:DNA ratio are based on $N=207$ tank means. Length-weight condition is based on $\mathrm{N}=610$ fish. In all graphs, black represents fed fish, and gray represents starved fish. WW: wet weight with mean weight $(\mathrm{RNA}-\mathrm{r}=-0.32, \mathrm{p}=0.0007$; DNA$\mathrm{r}=-0.43, \mathrm{p}=0.0001 ; \mathrm{DNA}: \mathrm{DW}-\mathrm{r}=-0.52, \mathrm{p}<0.0001$; $\mathrm{N}=207$ ), but RNA:DNA ratio was not significantly correlated with mean weight $(r=0.02, p=0.77 ; \mathrm{N}=207)$. These patterns held even when analyzed by treatment, for fed and starved fish. RNA:DNA ratio, lengthweight condition, and mean weight all showed greater positive changes in fed fish during the experiment; however, the increase in RNA:DNA ratio did not begin until Day 7 (Fig. 2).

\section{Field Expt 1, on enclosure growth}

\section{Environmental characteristics}

Environmental characteristics were typical of upper Breton Sound in early spring (Lane et al. 2007, Table 2). No treatment difference was found for water temperature, salinity, or dissolved oxygen, and daily fluctuations occurred in unison within and across treatments. Water temperature range during the enclosure experiment overlapped with the ambient temperature range during the laboratory experiment $\left(18\right.$ to $19^{\circ} \mathrm{C}_{i}$ Table 2). Turbidity was higher in inflow marshes, and average water depth was approximately $10 \mathrm{~cm}$ greater in reference marshes.

\section{Fish recovery}

Overall, 37 fish were recovered during the experiment. Fish recovery was lowest in the reference area (11 fish from 3 sites), likely owing to the high variability in water levels and the potential for marsh drying.

Fish growth

Overall mean daily somatic growth of fish in the inflow area was significantly higher than in the reference area (Table 3, Fig. 3). In the inflow area, the highest mean weight gain occurred at the site closest to the diversion structure, where the gain was double (0.001 $\mathrm{g} \mathrm{DW} \mathrm{d}^{-1}$ ) the overall mean daily weight gain observed in the inflow area (Table 3 ) and the same as the daily growth rate for fed fish in the laboratory experiment.

\section{Nucleic acid indices}

Mean RNA:DNA ratio of fish in the inflow area appeared greater than that in the reference area; however, this relationship was not significant at $\alpha=0.05$ 
Table 2. Field Expts 1 and 2. Environmental characteristics of upper Breton Sound estuary, Louisiana, during an extended winter-spring riverine pulse event beginning January 26, 2007. The enclosure experiment $(\mathrm{N}=40)$ began at Week 6 of the pulse and lasted $10 \mathrm{~d}$. The field collection experiment $(\mathrm{N}=6)$ began on the first day of the pulse event and lasted $7 \mathrm{wk}$. NTU $=$ nephelometer turbidity units

\begin{tabular}{|c|c|c|c|c|}
\hline \multirow[t]{2}{*}{ Variable } & \multicolumn{2}{|c|}{ Enclosure } & \multicolumn{2}{|c|}{ Field collection } \\
\hline & Inflow & Reference & Inflow & Reference \\
\hline \multicolumn{5}{|c|}{ Temperature $\left({ }^{\circ} \mathbf{C}\right)$} \\
\hline Mean \pm SE & $15.7 \pm 0.4$ & $15.8 \pm 0.20$ & $13.4 \pm 1.46$ & $14.3 \pm 2.31$ \\
\hline Range & 13.5 to 20.5 & 14.5 to 17.6 & 7.2 to 16.1 & 6.2 to 22.3 \\
\hline \multicolumn{5}{|l|}{ Salinity } \\
\hline Mean \pm SE & $0.2 \pm 0.00$ & $0.9 \pm 0.12$ & $0.2 \pm 0.01$ & $2.1 \pm 0.17$ \\
\hline Range & 0.2 to 0.2 & 0.23 to 2.08 & 0.2 to 0.2 & 1.7 to 2.7 \\
\hline \multicolumn{5}{|c|}{ Dissolved oxygen $\left(\mathrm{mg} \mathrm{l}^{-1}\right)$} \\
\hline Mean $\pm \mathrm{SE}$ & $8.4 \pm 0.13$ & $8.1 \pm 0.09$ & $5.9 \pm 0.88$ & $4.7 \pm 0.81$ \\
\hline Range & 6.6 to 9.3 & 7.3 to 8.7 & 3.6 to 8.4 & 2.2 to 7.6 \\
\hline \multicolumn{5}{|c|}{ Turbidity (NTU) } \\
\hline Mean \pm SE & $18.6 \pm 3.09$ & $8.4 \pm 1.06$ & $13.0 \pm 2.28$ & $4.4 \pm 1.24$ \\
\hline Range & 1.6 to 53.0 & 1.1 to 19.5 & 5.5 to 18.6 & 2.1 to 10.4 \\
\hline \multicolumn{5}{|c|}{ Water depth (mm) } \\
\hline Mean \pm SE & $201.8 \pm 10.46$ & $330.4 \pm 9.15$ & $173.2 \pm 15.7$ & $275.0 \pm 65.82$ \\
\hline Range & 122.4 to 314.2 & 223.6 to 400.4 & 125.0 to 215.0 & 150.0 to 510.0 \\
\hline
\end{tabular}

Table 3. Gambusia affinis . Field Expt 1, on enclosure. Summary statistics by treatment for morphometric and nucleic acid growth indices for wild-caught $G$. affinis during a short-term enclosure growth experiment in upper Breton Sound estuary, Louisiana, during an extended winter-spring riverine pulse event beginning January 26, 2007. The enclosure experiment began at Week 6 of the pulse and lasted $10 \mathrm{~d}$. The rate of change in total length (TL) is reported, as opposed to standard length (SL), in order to remain consistent across experiments. The change in SL was also measured, and the results are the same as TL. Inflowarea: $\mathrm{N}=4$, Reference area: $\mathrm{N}=3$. DW = dry weight

\begin{tabular}{|c|c|c|c|c|}
\hline \multirow{2}{*}{$\begin{array}{l}\text { Growth/ } \\
\text { condition index }\end{array}$} & \multirow[t]{2}{*}{ Inflow } & \multirow[t]{2}{*}{ Reference } & \multicolumn{2}{|c|}{ ANOVA } \\
\hline & & & $F_{1,5}$ & $\mathrm{p}$ \\
\hline \multicolumn{5}{|c|}{ Weight (g DW d ${ }^{-1}$ ) } \\
\hline Mean \pm SE & $0.0006 \pm 0.00$ & $-0.0001 \pm 0.00$ & 7.56 & 0.04 \\
\hline Range & -0.0004 to 0.003 & -0.001 to 0.002 & & \\
\hline $\mathrm{CV}(\%)$ & - & - & & \\
\hline \multicolumn{5}{|c|}{ Total length $\left(\mathrm{mm} \mathrm{d}^{-1}\right)$} \\
\hline Mean \pm SE & $0.08 \pm 0.01$ & $0.009 \pm 0.01$ & 15.53 & 0.0003 \\
\hline Range & 0.00 to 0.20 & 0.00 to 0.10 & & \\
\hline CV $(\%)$ & - & - & & \\
\hline \multicolumn{5}{|l|}{ RNA ( $\mu \mathrm{g} \mathrm{mg}^{-1}$ ) } \\
\hline Mean \pm SE & $3.46 \pm 0.42$ & $2.73 \pm 0.51$ & 0.94 & 0.38 \\
\hline Range & 0.63 to 7.89 & 0.38 to 5.45 & & \\
\hline $\mathrm{CV}(\%)$ & 48 & 62 & & \\
\hline \multicolumn{5}{|l|}{ DNA $\left(\mu g \mathrm{mg}^{-1}\right)$} \\
\hline Mean \pm SE & $0.44 \pm 0.05$ & $0.42 \pm 0.04$ & 0.03 & 0.87 \\
\hline Range & 0.14 to 0.87 & 0.24 to 0.69 & & \\
\hline $\mathrm{CV}(\%)$ & 42 & 35 & & \\
\hline \multicolumn{5}{|l|}{ RNA:DNA ratio } \\
\hline Mean \pm SE & $8.16 \pm 0.86$ & $6.07 \pm 0.80$ & 2.48 & 0.18 \\
\hline Range & 4.29 to 15.19 & 0.92 to 9.90 & & \\
\hline CV $(\%)$ & 41 & 44 & & \\
\hline \multicolumn{5}{|l|}{ DNA:DW } \\
\hline Mean \pm SE & $0.01 \pm 0.00$ & $0.01 \pm 0.00$ & 0.12 & 0.74 \\
\hline Range & 0.00 to 0.02 & 0.00 to 0.02 & & \\
\hline CV & 63 & 62 & & \\
\hline
\end{tabular}

(Fig. 3). Relative DNA content was also similar between treatments (Table 3).

\section{Length-weight condition}

Because of heterogeneity of slopes, condition of harvested fish (Fig. 3) was tested at the overall mean weight (1.15 g WW). Length-weight condition was similar in inflow $(y=3.3531 x+$ $\left.1.9283 ; r^{2}=0.95\right)$ and reference $(y=$ $\left.3.1252 x+2.1440 ; r^{2}=0.86\right)$ fish.

\section{Comparison of techniques}

A statistical difference was found only for somatic growth in this study; however, length-weight condition and RNA:DNA ratio both showed the similar trend of greater positive responses in inflow fish (Fig. 3). Relative DNA content did not show a pattern that would suggest greater growth in inflow fish.

\section{Field Expt 2, on through-pulse field collection}

\section{Environmental characteristics}

Environmental characteristics during the field collection were typical of upper Breton Sound throughout the study period (Lane et al. 2007; Table 2). No difference was found for water temperature or dissolved oxygen by treatment or week. Variation in environmental characteristics occurred across all sites and both treatments simultaneously. Again, the range of water temperature measured during the field collection experiment overlapped with ranges in both the laboratory $\left(18\right.$ to $\left.19^{\circ} \mathrm{C}\right)$ and enclosure experiments. Turbidity was higher in inflow marshes, while water depth and salinity were slightly greater in reference marshes.

Nucleic acids were successfully extracted and compared to somatic growth for 208 experimental fish (104 inflow, 104 reference). Experimental fish were mostly composed of adults 

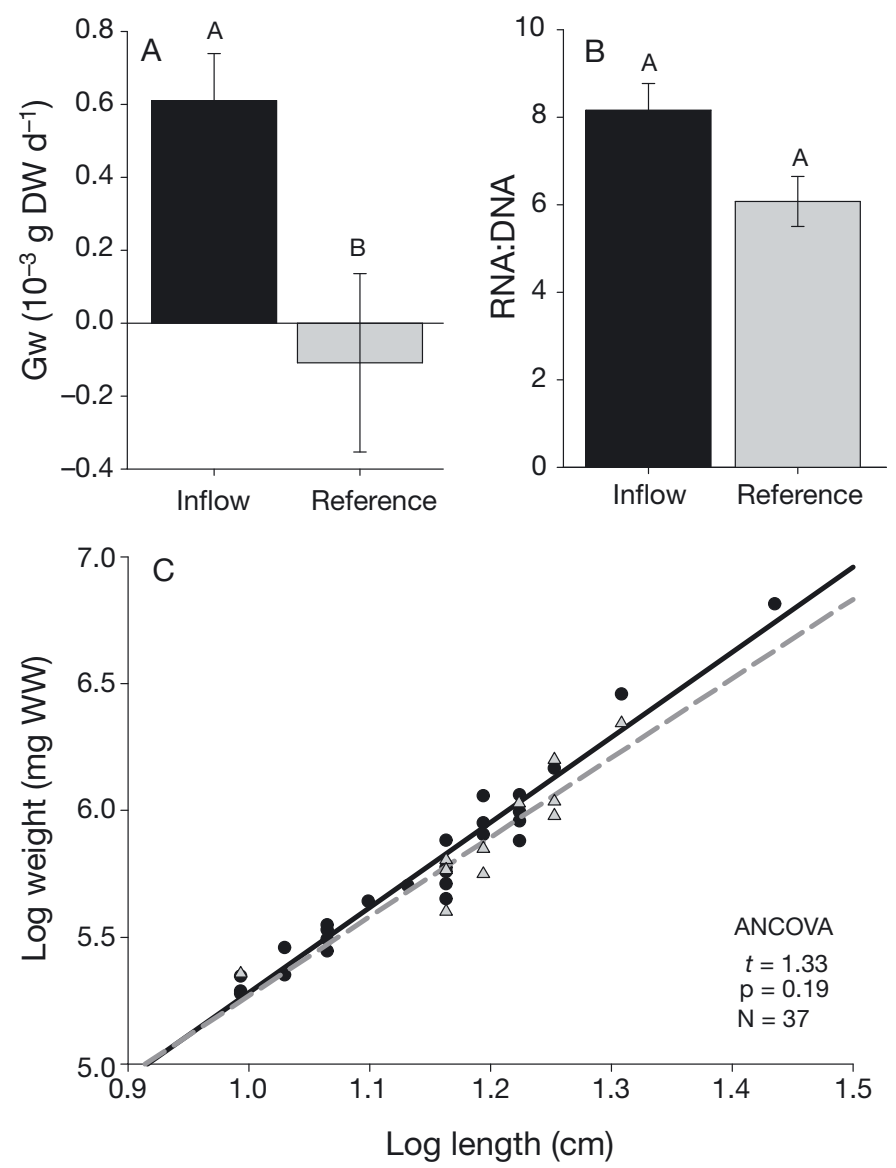

Fig. 3. Gambusia affinis. Field Expt 1, on enclosure growth. Comparison of (A) daily growth index, (B) RNA:DNA ratio, and $(C)$ length-weight condition for wild-caught $G$. affinis through a $10 \mathrm{~d}$ field enclosure growth experiment in upper Breton Sound, Louisiana. Inflow fish were contained in enclosures in flooded marsh habitat for $10 \mathrm{~d}$ beginning at Week 6 of an extended freshwater pulse event downstream from the Caernarvon Freshwater Diversion. Reference fish were contained in flooded marsh habitat unaffected by the freshwater pulse. Comparisons of growth rate and RNA:DNA ratio are based on $\mathrm{N}=7$ tank means, and letters denote statistical significance between treatment areas. Length-weight condition shows the condition of each individual recaptured fish (26 inflow, 11 reference). All graphs-black: inflow fish; gray: reference fish

(95\%) and females (90\%). Because only 1 juvenile was caught in the reference area, we were not able to compare responses by ontogeny. Analyses of lengthweight condition and energy density were performed on 1828 experimental fish, although they were transformed into $\mathrm{N}=36$ one-gram pellets (22 inflow, 14 reference) for energy density analysis.

Fish growth

Overall mean $( \pm \mathrm{SE})$ weight and length of experimental Gambusia affinis were $0.24 \pm 0.01 \mathrm{~g}$ WW
$(0.05 \pm 0.00 \mathrm{~g} \mathrm{DW})$ and $28.35 \pm 0.27 \mathrm{~mm}$ TL, respectively. Regression analysis showed no significant weekly growth pattern in weight or length from fish caught in the inflow area (Weight $[g$ DW] $=-0.0007$ [wk] $\left.\left.+0.04 ; \mathrm{r}^{2}=0.01 ; \mathrm{p}=0.42 ; \mathrm{N}=104\right]\right)$ and total length (Length $[\mathrm{mm}]=-0.19[\mathrm{wk}]+29.05 ; \mathrm{r}^{2}=0.01$; $\mathrm{p}=0.26 ; \mathrm{N}=104)$. A significant negative weekly relationship existed for both fish weight (Weight [g $\mathrm{DW}]=-0.007[\mathrm{wk}]+0.076 ; \mathrm{r}^{2}=0.34 ; \mathrm{p}<0.0001 ; \mathrm{N}=$ 104) and total length (Length $[\mathrm{mm}]=-1.41[\mathrm{wk}]+$ $\left.34.06 ; \mathrm{r}^{2}=0.41 ; \mathrm{p}<0.0001 ; \mathrm{N}=104\right)$ in the reference area. No difference was found between slopes $(F=$ $0.95, \mathrm{p}=0.33$ ) for weight, but slopes were significantly different by treatment for mean length $(F=$ 3.80, $\mathrm{p}=0.05)$.

\section{Nucleic acid indices}

RNA:DNA ratio and relative DNA content were highly variable throughout the experiment (Table 4). Nucleic acid concentrations correlated positively with each other $(\mathrm{r}=0.16, \mathrm{p}=0.02 ; \mathrm{N}=208)$, and RNA:DNA ratio correlated positively with RNA concentrations $(\mathrm{r}=0.80, \mathrm{p}<0.0001 ; \mathrm{N}=208)$ and negatively with DNA concentrations $(\mathrm{r}=-0.28, \mathrm{p}<0.0001$; $\mathrm{N}=208$ ). Regression analysis showed a significant weekly increase in RNA:DNA ratio for both inflow fish (RNA:DNA $=2.28$ [wk] $-2.98 ; \mathrm{r}^{2}=0.30 ; \mathrm{p}<$ $0.0001 ; \mathrm{N}=104)$ and reference fish (RNA:DNA $=1.60$ $\left.[\mathrm{wk}]+0.68 ; \mathrm{r}^{2}=0.24 ; \mathrm{p}<0.0001 ; \mathrm{N}=104\right)$, with a greater increase in inflow fish as compared to reference fish. However, this difference in slopes was not significant $(F=0.09, \mathrm{p}=0.76)$. Relative DNA content showed no weekly relationship in inflow fish (DNA:DW $=-0.0001[\mathrm{wk}]+0.01 ; \mathrm{r}^{2}=0.001 ; \mathrm{p}=0.79$; $\mathrm{N}=104$ ) and a significant positive weekly relationship in reference fish (DNA:DW= 0.003 [wk] + 0.005; $\left.\mathrm{r}^{2}=0.10 ; \mathrm{p}=0.0008 ; \mathrm{N}=104\right)$, and these slopes were significantly different $(F=6.75, \mathrm{p}=0.01)$.

\section{Length-weight condition}

Condition of harvested fish was tested at the $y$ intercept, because slopes were homogeneous. Overall length-weight condition was significantly higher in reference fish $\left(y=2.8140 x-4.2528 ; r^{2}=0.89 ; \mathrm{N}=\right.$ 1044) than inflow fish $\left(y=2.8908 x-4.3808 ; r^{2}=0.91\right.$; $\mathrm{N}=784$; Fig. 4). Analysis by week showed that in the first $4 \mathrm{wk}$, the index was higher for reference fish for 3 wk (Weeks 2, 3, and 4). At Week 5, the index showed no difference in value between treatments, and this pattern remained constant through Weeks 6 and 7 . 
Table 4. Gambusia affinis. Field Expt 2, on through-pulse field collection. Summary statistics by treatment for nucleic acid growth indices for wild-caught $G$. affinis during a throughpulse field collection experiment in upper Breton Sound estuary, Louisiana, during an extended winter-spring riverine pulse event beginning January 26, 2007. The field collection experiment began on the first day of the pulse event and lasted 7 wk. Inflow area: $\mathrm{N}=104$, Reference area: $\mathrm{N}=104$

\begin{tabular}{|c|c|c|}
\hline $\begin{array}{l}\text { Growth/ } \\
\text { condition index }\end{array}$ & Inflow & Reference \\
\hline \multicolumn{3}{|l|}{ RNA $\left(\mu \mathrm{g} \mathrm{mg}{ }^{-1}\right)$} \\
\hline Mean \pm SE & $2.54 \pm 0.18$ & $3.24 \pm 0.18$ \\
\hline Range & 0.01 to 15.24 & 0.30 to 15.31 \\
\hline CV (\%) & 104 & 83 \\
\hline \multicolumn{3}{|l|}{ DNA $\left(\mu g \mathrm{mg}^{-1}\right)$} \\
\hline Mean \pm SE & $0.51 \pm 0.02$ & $0.51 \pm 0.02$ \\
\hline Range & 0.08 to 1.34 & 0.14 to 1.63 \\
\hline CV (\%) & 45 & 51 \\
\hline \multicolumn{3}{|l|}{ RNA:DNA ratio } \\
\hline Mean \pm SE & $6.21 \pm 0.58$ & $7.15 \pm 0.45$ \\
\hline Range & 0.03 to 46.63 & 1.20 to 38.63 \\
\hline CV $(\%)$ & 134 & 92 \\
\hline \multicolumn{3}{|l|}{ DNA:DW } \\
\hline Mean \pm SE & $0.01 \pm 0.00$ & $0.02 \pm 0.00$ \\
\hline Range & 0.00 to 0.04 & 0.00 to 0.10 \\
\hline CV (\%) & 70 & 112 \\
\hline
\end{tabular}

\section{Energy density}

Overall mean energy density of experimental Gambusia affinis during the 2007 freshwater pulse event was $6242 \pm 40.79 \mathrm{cal} \mathrm{g}^{-1}$ (range from 4863 to $6719 \mathrm{cal}$ $\mathrm{g}^{-1}$ ). Regression analysis showed a significant weekly increase in energy density for inflow fish (Energy [cal $\left.\mathrm{g}^{-1}\right]=80.08[\mathrm{wk}]+5855.09 ; \mathrm{r}^{2}=0.28 ; \mathrm{p}<0.01 ; \mathrm{N}=22$ ) No weekly relationship was found for reference fish (Energy $\left[\mathrm{cal} \mathrm{g}^{-1}\right]=-16.00[\mathrm{wk}]+6518.65 ; \mathrm{r}^{2}=0.02 ; \mathrm{p}<$ $0.60 ; \mathrm{N}=14$ ). Slopes were significantly different by treatment $(F=4.93, \mathrm{p}=0.03)$. The largest increase in energy density occurred in the inflow samples and was observed during Weeks 1 through 3, with a second, but smaller increase observed between Weeks 6 and 7 .

\section{Comparison of techniques}

General patterns of change were similar among indices (Fig. 4). Values for mean weight, somatic growth, RNA:DNA density, energy density, and length-weight condition were initially lower in inflow fish, but over the course of the experiment, inflow fish showed greater positive increases and higher ending values. Differences were detected in the timing of increase among indices. In particular, while morphometric and energy density indices all responded within the first 4 to $5 \mathrm{wk}$ of the pulse event, RNA:DNA ratio began responding at Week 7 (Fig. 4). As in the laboratory experiment, RNA and DNA concentrations, as well as relative DNA content, were significantly negatively correlated with mean weight (RNA $-\mathrm{r}=-0.34$, $\mathrm{p}<0.0001$; DNA-r $=-0.43, \mathrm{p}<0.0001 ; \mathrm{DNA}: \mathrm{DW}-\mathrm{r}=$ $-0.67, \mathrm{p}<0.0001 ; \mathrm{N}=208)$, but RNA:DNA ratio was not significantly correlated with mean weight $(\mathrm{r}=-0.12$, $\mathrm{p}=0.08 ; \mathrm{N}=208$ ). Energy density was not significantly correlated with mean weight $(\mathrm{r}=0.07, \mathrm{p}=0.81 ; \mathrm{N}=36$ pellets composed of 1828 fish).

\section{DISCUSSION}

Indices all indicated that marshes flooded by Caernarvon were capable of producing higher growth rates in Gambusia affinis than reference sites lacking freshwater inflow. Although morphometric and biochemical indices were generally not directly correlated in our experiments, their response patterns were similar in terms of the direction and magnitude of change, indicating clear differences in the response time and sensitivity of the indicators. Specifically, daily growth, length-weight condition, mean weight, and energy density measures all showed a relatively rapid response to treatments, while RNA:DNA ratio did not appear to be as sensitive to growth changes, and had slower detectable responses. While all of the indices appear to be potential candidates as field based indicators for assessment of fisheries resources, understanding the response time of selected indicators is key for interpretation and analysis.

\section{Growth and habitat quality}

Indices all indicated that marshes flooded by Caernarvon were capable of supporting rapid growth in experimental fish and that these marshes represented energetically valuable habitat to support trophic transport. Interestingly, fish in inflow field enclosures grew at rates approaching those held under laboratory conditions (ad libitum feeding, no predation, stable water temperature), suggesting that inflow marshes provided a highly favorable growth environment for Gambusia affinis. G. affinis in inflow marshes grew at a similar rate to that of other estuarine residents (G. affinis, Wurtsbaugh \& Cech 1983; Fundulus heteroclitus, Kneib \& Stiven 1978) and transient species (Sciaenops ocellatus, Stunz et al. 2002; Leiostomus xanthurus, Weinstein \& Walters 1981; Pseudopleuronectes americanus, Sogard 1992, Meng et al. 2000; Tautoga onitis, Sogard 1992). The energy density index also indicated positive growth and energy in 

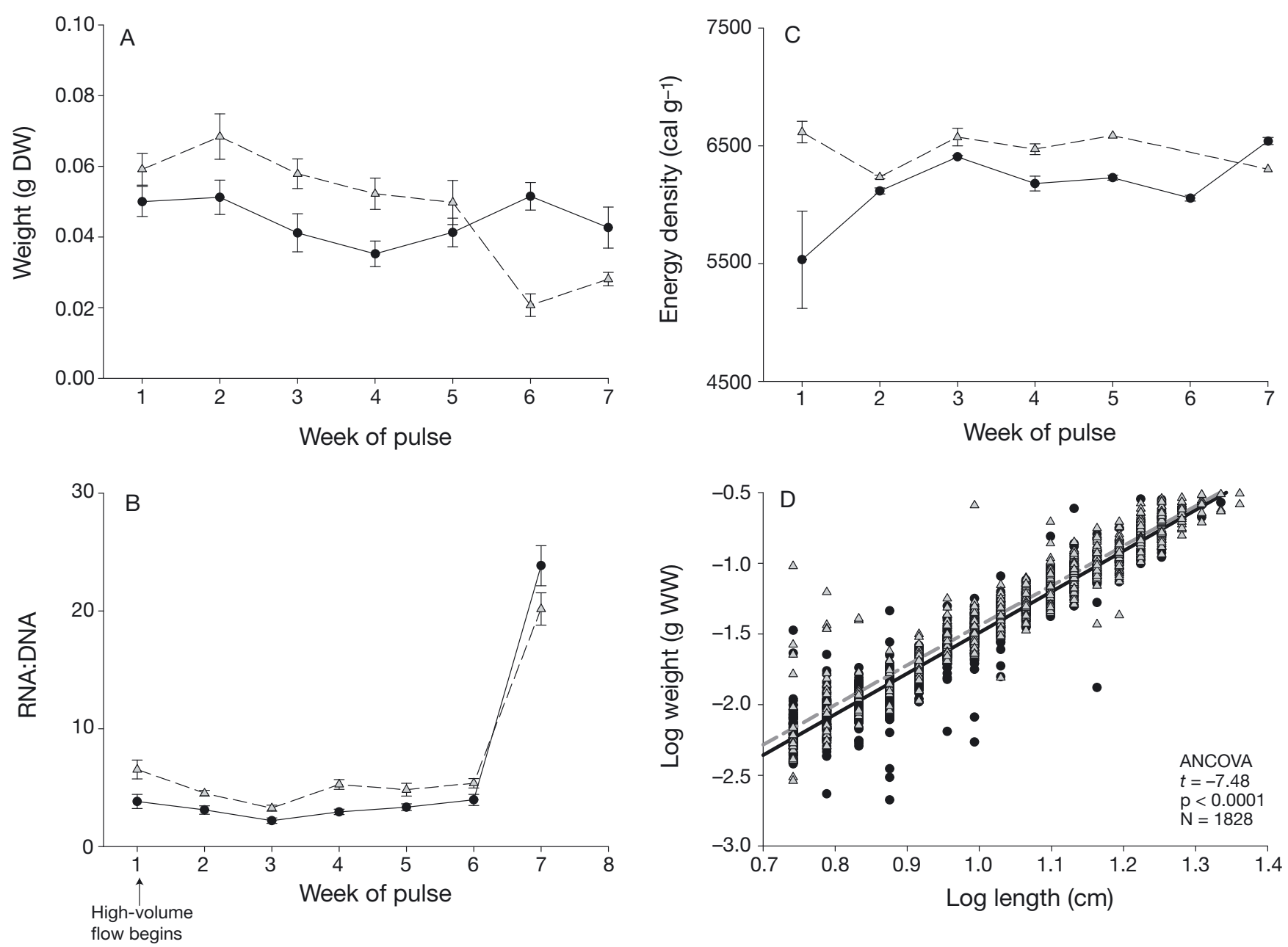

Fig. 4. Gambusia affinis. Field Expt 2, on through-pulse field collection. Comparison of (A) weekly mean weight and (B) RNA:DNA indices, as well as (C) weekly energy density and (D) length-weight condition for wild-caught $G$. affinis through a 7 wk freshwater pulse event in upper Breton Sound, Louisiana. Inflow fish were captured weekly in flooded marsh habitat downstream from the Caernarvon Freshwater Diversion, beginning on the first day of the pulse event. Reference fish were captured weekly in flooded marsh habitat unaffected by the freshwater pulse. Comparisons of growth rate and RNA:DNA ratio are based on $\mathrm{N}=208$ fish (104 inflow, 104 reference), and comparisons of energy density and length-weight condition are based on $\mathrm{N}=1828$ fish. All graphs_-black: inflow fish; gray: reference fish. WW: wet weight

inflow throughout the pulse event, and G. affinis in inflow marshes contained similar amounts of energy to other species of forage fish (Perez 1994, Tierney et al. 2002, Wanless et al. 2005).

Weekly field-collection results showed a significant increase in energy density in fish captured in the inflow area during Weeks 1 through 3 of the freshwater pulse, while all other indices showed greater fish size and condition in reference marshes. This initial rapid increase in energy in the inflow marsh immediately following the start of the pulse may be capturing a feeding pulse resulting from fish access to newly flooded habitat, thus providing an immediate indication of an increase in food availability, an important component of habitat quality. A second growth-related pulse may have begun during Week 5 of the fresh- water pulse, as evidenced by an increase in size and condition in inflow fish. Such a delayed response by some fish may be due to a delayed prey response or a secondary peak in prey items for Gambusia affinis, such as invertebrates and mosquitoes. Studies have shown that flood events temporarily decrease invertebrate abundance in aquatic systems; however, populations recover within days to months (Dodds et al. 2004). One study on intermittently flooded streams found that peak benthic macroinvertebrate density and diversity were found 40 to $60 \mathrm{~d}$ after flood events (Dodds et al. 2004). Flooding has also been shown to stimulate the laying and hatch of mosquito eggs, and evidence suggests that full cohort development for mosquitoes at water temperatures similar to those seen in our study takes from 30 to $40 \mathrm{~d}$ (Fontanarrosa et al. 2000). 
Alternatively, weekly sampling may simply have documented a difference in the size distribution of fish, resulting from life history plasticity in Gambusia affinis. Experimental fish in the reference area may be on a different developmental schedule than fish in the inflow area, and larger individuals in the reference area in the early weeks of the pulse may have been gravid overwintering females that produced young and died off by the end of the collection period. A dieoff of large adult fish would leave smaller, faster growing fish in the population and may explain the negative temporal growth relationships (length and weight) found during the weekly collections, as well as the sudden increase in RNA:DNA ratio during Week 7 in the reference area. It is not uncommon to see variability in size, growth, and population dynamics in fishes, and particularly Poecilliids, that are collected in proximity to one another, especially when there are differences in hydrologic disturbance patterns (Trendall 1983).

The differences in timing of responses of different indicators show the importance of examining habitat quality over appropriate temporal scales (Rountree \& Able 2007) and suggest caution in selecting only one indicator or experimentation method for interpretation and analysis. These results also highlight the potential importance of the duration of seasonal flood pulses for ecosystem productivity (Odum et al. 1995).

\section{Growth indices}

Morphometric and biochemical indices were generally not directly correlated. However, except for the timing of changes, the indices produced general agreement in response and pattern. This is an interesting finding because correlations are often used to assess growth indices, but relationships are often timedependent. This relationship was found in a similar study that compared biochemical and somatic indices in wild-caught fish in Portuguese estuaries and highlights the need to look at the time-evolution of response, due to latency in response of individuals to changes in environmental factors and food availability (Vasconcelos et al. 2009). For example, the RNA:DNA ratio did not appear to be a good predictor of growth when based on a direct correlation with morphometric indices. However, the response pattern of the RNA: DNA ratio generally agreed with somatic growth (mean weight, length, length-weight condition) in all experiments. Interestingly, the response pattern for the RNA:DNA ratio was consistently slower than that of the morphometric indices. This slower response was unexpected, as biochemical indices and specifically the RNA:DNA ratio are held to be highly sensitive to growth, with rapid response times (1 to $2 \mathrm{~d}_{\text {i }}$ Richard et al. 1991, Rooker et al. 1997).

These slower responses and seemingly contrary relationships observed in the RNA:DNA ratio (higher ratio in starved fish, slower response times) may be related to biochemical responses of RNA with changes in fitness, particularly in starved fish, and age. Individual fitness may cause deviation between the expected relationship between RNA and growth, based on the mode of protein synthesis employed by the cell: increased ribosome number or increased ribosome activity (Lied et al. 1983). For example, it may be metabolically advantageous for actively growing fish to employ the mechanism of increased ribosomal activity, which translates into an inverse relationship between RNA and morphometric growth indices, due to lower RNA concentrations (Mathers et al. 1993). Conversely, the metabolic need for more protein synthesis in fish in poor condition may be mitigated by an increase in the number of ribosomes (RNA), which also translates into an inverse relationship between RNA and morphometric growth indices, due to decreased weight (Mathers et al. 1993). Lastly, a starving fish may show a compensatory survival mechanism that causes a spike in RNA in an attempt to produce energy as rapidly as possible (Raae et al. 1988). These fitness-based cellular growth mechanisms make it possible for starving fish to have higher RNA:DNA ratios than fed fish with high fitness, a result that we saw in the laboratory experiment. Other results also pointed to fitness-based cellular mechanisms: (1) lower RNA concentrations in fed fish; (2) negative relationships between RNA and morphometric growth indices, driven by the fed treatment, and (3) spike in RNA:DNA in starved fish on Day 10 that coincided with accelerated fish death. Additionally, Rooker \& Holt (1996) found a relative decline of $40 \%$ in RNA:DNA with age between larval and juvenile red drum, Sciaenops ocellatus, which implies an increased ability to mitigate starvation effects at the cellular level as an animal matures.

Despite its high variability, RNA:DNA ratio appeared to produce relatively consistent results across all experiments in our study and helped provide a comprehensive view of fish growth, especially when reliance on morphometric indices alone led to questions of interpretation. For example, during the field collections experiment, while there was some question as to what drove the shift in size distribution, the RNA:DNA ratio agreed with the energy density index, a measure of energy-rich protein and lipid tissue, which showed significant positive growth in inflow fish, through the pulse. This consistency was not expected in our study, as the RNA:DNA ratio has not typically been a successful index in wild-caught and adult fish because it relies on the unstable RNA mole- 
cule and is sensitive to cellular processes involved with reproduction and cellular growth dynamics as fish age (Bergeron 1997, Buckley et al. 1999).

Because of the range of water temperatures found in the field studies (enclosure experiment $\sim 6^{\circ} \mathrm{C}$; field collection $\sim 16^{\circ} \mathrm{C}$ ), temperature had the potential to affect the RNA:DNA ratio as a growth indicator in our field experiment. Temperature affects fish growth (Buckley et al. 1999, Searcy et al. 2007) and the RNA:DNA ratio by affecting the cellular rate of protein translation (Buckley et al. 1999, Mercado-Allen et al. 2006). In our studies, water temperatures did not differ by treatment in the laboratory or in the field. For example, the temperature may have been a factor that caused the sudden and large increase in the RNA:DNA ratio in Week 7 , as that is the week in which highest temperatures were recorded. The temperature effect is important to consider when designing experiments or using growth indices where temperature ranges and fluctuations may be not be similar between treatments. While we could not firmly assess the effect of temperature on growth and the RNA:DNA ratio in this study, it is important to note that though general temperature trends have been documented (Buckley et al. 1999), there is often considerable overlap in nucleic acid values and RNA:DNA ratios in laboratory experiments where differences in temperature treatments range from $2^{\circ}$ to $8^{\circ} \mathrm{C}$ (e.g. see Canino 1994, Caldarone 2005). For our field study, as fluctuations occurred in unison, the greatest differences in temperatures, on the basis of minimum and maximum values, were $6.2^{\circ} \mathrm{C}$ during the $7 \mathrm{wk}$ study and $3.1^{\circ} \mathrm{C}$ during the enclosure study, and thus were not likely a controlling factor in the RNA:DNA ratio. Additionally, diel variation in water temperature has been suggested as potentially influencing the RNA:DNA ratio; the only study that we are aware of that explicitly examined this failed to find that temperature variation had an effect on diel variations in biochemical condition in Sciaenops ocellatus (Rooker \& Holt 1996). Food availability, more than temperature, has also been shown to affect growth and the expression of the RNA:DNA ratio (Buckley et al. 1984), suggesting that, as long as temperature differences between treatments are comparable, fish growth and the RNA:DNA ratio are appropriate indicators of habitat quality.

Because of its dependence on body weight, the relative DNA content index was able to detect growth changes when significant changes in weight occurred, but this index does not appear to be a very sensitive or useful indicator. During the field collection experiment, although relative DNA content showed a significant relationship that corresponded to the loss of weight in reference fish, the indicator provided no additional information that would have provided a more comprehensive view of fish growth in discretely caught wild fish.

\section{CONCLUSIONS}

Our growth study showed that marshes flooded by restored freshwater pulsing were capable of producing optimum growth and energetically valuable habitat to support trophic transport, and, despite high variability, many common morphometric and biochemical growth indices led to the same conclusions about the habitat quality for wild Gambusia affinis. Our findings (1) highlight the importance of understanding the sensitivity of individual indices as well as their response time to changes in habitat quality and (2) contrast with other field studies in which the high variability of RNA:DNA ratios from one-time sampling of wildcaught fish precludes the ability of the index to integrate habitat effects (e.g. Rooker et al. 1997). These results also suggest that any of the growth indices measured on discretely caught wild fish are useful as indicators to monitor and assess habitat quality as long as the sampling period is long enough to take into account both the sensitivity of the technique and the delayed habitat effects that result from the management actions. Further studies in this area should incorporate multiple targeted short-term growth experiments to supplement discrete field sampling in order to provide comparison of the indices over longer time scales that would further refine our understanding of habitat function and benefit rapid assessment techniques. This is an area of applied research that will be of great benefit to wetland habitat restoration and management programs.

Acknowledgements. We thank the following people for their assistance with this project: D. King, W. Gayle, B. Gossman, C. Llewellyn, and M. Piehler, for field and laboratory assistance; D. Kelly, J. La Peyre, and N. Itoh for laboratory access and assistance with nucleic acid purification and quantification; C. Espineda (Qiagen, Inc.) for technical assistance with the Qiagen AllPrep DNA/RNA Mini Kit; A. Fischer and J. Cowan for access to and assistance with the bomb calorimeter. M. Passerotti (NOAA), S. Piazza (USGS), and K. Cretini (USGS) reviewed the manuscript. This study was funded by Coastal Restoration and Enhancement through Science and Technology (CREST), LSU Sea Grant College Program (Undergraduate Research Opportunity Program), and the Louisiana Department of Wildlife and Fisheries.

\section{LITERATURE CITED}

Amara R, Meziane T, Gilliers C, Hermel G, Laffargue P (2007) Growth and condition indices in juvenile sole Solea solea measured to assess the quality of essential fish habitat. Mar Ecol Prog Ser 351:201-208 
Bergeron JP (1997) Nucleic acids in ichthyoplankton ecology: a review, with emphasis on recent advances for new perspectives. J Fish Biol 51:284-302

Buckley LJ, Turner SI, Halavik TA, Smigielski AS, Drew SM, Lawrence GC (1984) Effects of temperature and food availability on growth, survival, and RNA-DNA ratio of larval sand lance (Ammodytes americanus). Mar Ecol Prog Ser 15:91-97

Buckley L, Caldarone E, Ong TL (1999) RNA-DNA ratio and other nucleic acid-based indicators for growth and condition of marine fishes. Hydrobiologia 401:265-277

> Caldarone EM (2005) Estimating growth in haddock larvae Melanogrammus aeglefinus from RNA:DNA ratios and water temperature. Mar Ecol Prog Ser 293:241-252

Canino MF (1994) Effects of temperature and food availability on growth and RNA/DNA ratios of walleye pollock Theragra chalcogramma (Pallas) eggs and larvae. J Exp Mar Biol Ecol 175:1-16

> Dodds WK, Gido K, Whiles MR, Fritz KM, Matthews WJ (2004) Life on the edge: the ecology of Great Plains prairie streams. Bioscience 54:205-216

Fontanarrosa MS, Marinone MC, Fischer S, Orellano PW, Schweigmann N (2000) Effects of flooding and temperature on Aedes albifasciatus development time and larval density in two rain pools at Buenos Aires University city. Mem Inst Oswaldo Cruz 95:787-793

Gilliers C, Amara R, Bergeron JP, Le Pape O (2004) Comparison of growth and condition indices of juvenile flatfish in different coastal nursery grounds. Environ Biol Fishes 71: 189-198

- Haas HL, Freeman CJ, Logan JM, Deegan L, Gaines EF (2009) Examining mummichog growth and movement: Are some individuals making intra-season migrations to optimize growth? J Exp Mar Biol Ecol 369:8-16

Hughes AL (1985) Seasonal changes in fecundity and size at first reproduction in an Indiana population of the mosquitofish Gambusia affinis. Am Midl Nat 114:30-36

Kneib RT (2000) Saltmarsh ecoscapes and production transfers by estuarine nekton in the southeastern United States. In: Weinstein MP, Kreeger DA (eds) Concepts and controversies in tidal marsh ecology. Kluwer, Boston, MA, p 267-291

Kneib RT, Stiven AE (1978) Growth, reproduction, and feeding of Fundulus heteroclitus (L.) on a North Carolina salt marsh. J Exp Mar Biol Ecol 31:121-140

> La Peyre MK, Gossman B, Nyman JA (2007) Assessing functional equivalency of nekton habitat in enhanced habitats: comparison of terraced and unterraced marsh ponds. Estuar Coast 30:526-536

Lane RR, Day JW Jr, Marx BD, Reyes E, Hyfield E, Day JN (2007) The effects of riverine discharge on temperature, salinity, suspended sediment and chlorophyll $a$ in a Mississippi delta estuary measured using a flow-through system. Estuar Coast Shelf Sci 74:145-154

Lied E, Rosenlund G, Lund B, von der Decken A (1983) Effect of starvation and refeeding on in vitro protein synthesis in white trunk muscle of Atlantic cod (Gadus morhua). Comp Biochem Physiol 76B:777-781

Lorenzen K, Enberg K (2002) Density-dependent growth as a key mechanism in the regulation of fish populations: evidence from among-population comparisons. Proc R Soc Lond B Biol Sci 269:49-54

Madon SP (2008) Fish community responses to ecosystem stressors in coastal estuarine wetlands: a functional basis for wetlands management and restoration. Wetl Ecol Manag 16:219-236

Mathers EM, Houlihan DF, McCarthy ID, Burren LJ (1993)
Rates of growth and protein synthesis correlated with nucleic acid content in fry of rainbow trout, Oncorhynchus mykiss: effects of age and temperature. J Fish Biol 43: $245-263$

Meng L, Gray C, Taplin B, Kupcha E (2000) Using winter flounder growth rates to assess habitat quality in Rhode Island's coastal lagoons. Mar Ecol Prog Ser 201:287-299

Mercaldo-Allen R, Kuropat C, Caldarone EM (2006) A model to estimate growth in young-of-the-year tautog, Tautoga onitis, based on RNA/DNA ratio and seawater temperature. J Exp Mar Biol Ecol 329:187-195

> Odum WE, Odum EP, Odum HT (1995) Nature's pulsing paradigm. Estuaries 18:547-555

> Oliva-Paterna FJ, Miñano PA, Torralva M (2003) Habitat quality affects the condition of Barbus sclateri in Mediterranean semi-arid streams. Environ Biol Fishes 67:13-22

Pedersen RA (1971) DNA content, ribosomal gene multiplicity, and cell size in fish. J Exp Zool 177:65-78

Perez MA (1994) Calorimetry measurements of energy value of some Alaskan fishes and squids. US Department of Commerce, NOAA Technical Memorandum. NMFSAFSC-32

Piazza BP (2009) The role of climate variability and riverine pulsing in the community dynamics of estuarine nekton in Breton Sound, Louisiana. PhD dissertation, Louisiana State University, Baton Rouge

> Piazza BP, La Peyre MK (2007) Restoration of the annual flood pulse in Breton Sound, Louisiana, USA: habitat change and nekton community response. Aquat Biol 1:109-119

> Raae AJ, Opstad I, Kvenseth P, Walther B Th (1988) RNA, DNA and protein during early development in feeding and starved Cod (Gadus morhua L.) larvae. Aquaculture 73:247-259

> Richard P, Bergeron JP, Boulhic M, Galois R, Person-Le Ruyet J (1991) Effect of starvation on RNA, DNA and protein content of laboratory-reared larvae and juvenile of Solea solea. Mar Ecol Prog Ser 72:69-77

Rooker JR, Holt GJ (1996) Application of RNA:DNA ratios to evaluate the condition and growth of larval and juvenile red drum (Sciaenops ocellatus). Mar Freshw Res 47: $283-290$

Rooker JR, Holt GJ, Holt SA (1997) Condition of larval and juvenile red drum (Sciaenops ocellatus) from estuarine nursery habitats. Mar Biol 127:387-394

> Rountree RA, Able KW (2007) Spatial and temporal habitat use patterns for salt marsh nekton: implications for ecological functions. Aquat Ecol 41:25-45

> Rozas LP (1995) Hydroperiod and its influence on nekton use of the salt marsh: a pulsing ecosystem. Estuaries 18: 579-590

Rozas LP, Minello TJ, Munuera-Fernández E, Fry B, Wissel B (2005) Macrofaunal distributions and habitat change following winter-spring releases of freshwater into the Breton Sound estuary, Louisiana (USA). Estuar Coast Shelf Sci 65:319-336

Searcy SP, Eggleston DB, Hare JA (2007) Is growth a reliable indicator of habitat quality and essential fish habitat for a juvenile estuarine fish? Can J Fish Aquat Sci 64:681-691

Snedden GA, Cable JE, Swarzenski C, Swenson E (2007) Sediment discharge into a subsiding Louisiana deltaic estuary through a Mississippi River diversion. Estuar Coast Shelf Sci 71:181-193

Sogard SM (1992) Variability in growth rates of juvenile fishes in different estuarine habitats. Mar Ecol Prog Ser 85: 35-53

> Stunz GW, Minello TJ, Levin PS (2002) Growth of newly settled red drum Sciaenops ocellatus in different estuarine 
habitat types. Mar Ecol Prog Ser 238:227-236

Teal LR, de Leeuw JJ, van der Veer HW, Rijnsdorp AD (2008) Effects of climate change on growth of 0-group sole and plaice. Mar Ecol Prog Ser 358:219-230

Tierney M, Hindell M, Goldsworthy S (2002) Energy content of mesopelagic fish from Macquarie Island. Antarct Sci 14: $225-230$

Trendall JT (1983) Life history variation among experimental populations of the mosquitofish, Gambusia affinis. Copeia 1983:953-963

> Vasconcelos RP, Reis-Santos P, Fonseca V, Ruano M, Tanner S, Costa MJ, Cabral HN (2009) Juvenile fish condition in estuarine nurseries along the Portuguese coast. Estuar Coast Shelf Sci 82:128-138

Vila-Gispert A, Moreno-Amich R (2001) Mass-length relationship of Mediterranean barbel as an indicator of environmental status in southwest European stream ecosystems. J Fish Biol 59:824-832

Vondracek B, Wurtsbaugh WA, Cech JJ Jr (1988) Growth and reproduction of the mosquitofish, Gambusia affinis, in relation to temperature and ration level: consequences for life history. Environ Biol Fishes 21:45-57

Editorial responsibility: Kenneth Heck Jr., Dauphin Island, Alabama, USA
Wanless S, Harris MP, Redman P, Speakman JR (2005) Low energy values of fish as a probable cause of a major seabird breeding failure in the North Sea. Mar Ecol Prog Ser 294:1-8

Weber LP, Higgins PS, Carlson RI, Janz DM (2003) Development and validation of methods for measuring multiple biochemical indices of condition in juvenile fishes. J Fish Biol 63:637-658

Weinstein MP, Walters MP (1981) Growth, survival and production in young-of-the-year populations of Leiostomus xanthurus Lacépéde residing in tidal creeks. Estuaries 4: 185-197

Wurtsbaugh WA, Cech JJ Jr (1983) Growth and activity of juvenile mosquitofish: temperature and ration effects. Trans Am Fish Soc 112:653-660

$>$ Zapfe GA, Rakocinski CF (2008) Coherent growth and diet patterns in juvenile spot (Leiostomus xanthurus Lacepéde) reflect effects of hydrology on access to shoreline habitat. Fish Res 91:107-111

Zarnoch SJ (2009) Testing hypotheses for differences between linear regression lines. US Dept Agr, US For Serv, e-research note SRS-17

Submitted: July 14, 2009; Accepted: April 9, 2010

Proofs received from author(s): August 4, 2010 